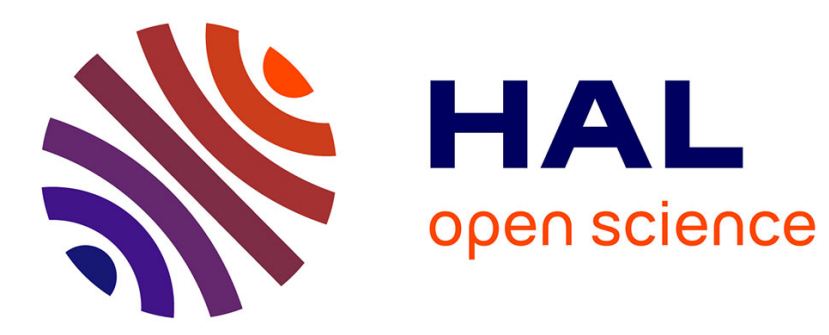

\title{
Sintering temperature dependence of the photothermal spectra in ceramic CdS
}

T. Toyoda, M. Sorazawa, S. Ando

\section{To cite this version:}

T. Toyoda, M. Sorazawa, S. Ando. Sintering temperature dependence of the photothermal spectra in ceramic CdS. Journal de Physique IV Proceedings, 1994, 04 (C7), pp.C7-315-C7-318. 10.1051/jp4:1994775 . jpa-00253304

\section{HAL Id: jpa-00253304 https://hal.science/jpa-00253304}

Submitted on 1 Jan 1994

HAL is a multi-disciplinary open access archive for the deposit and dissemination of scientific research documents, whether they are published or not. The documents may come from teaching and research institutions in France or abroad, or from public or private research centers.
L'archive ouverte pluridisciplinaire HAL, est destinée au dépôt et à la diffusion de documents scientifiques de niveau recherche, publiés ou non, émanant des établissements d'enseignement et de recherche français ou étrangers, des laboratoires publics ou privés. 
JOURNAL DE PHYSIQUE IV

Colloque C7, supplément au Journal de Physique III, Volume 4, juillet 1994

\title{
Sintering temperature dependence of the photothermal spectra in ceramic CdS
}

T. Toyoda, M. Sorazawa and S. Ando

Department of Applied Physics and Chemistry, The University of Electro-Communications,

1-5-I Chofugaoka, Chofu, Tokyo I82, Japan

\begin{abstract}
Photothermal spectroscopy using a thermistor is applied to study the heat generation by nonradiative processes in ceramic CdS. It is found that photothermal spectra of ceramic CdS depend on the sintering temperature; $i$.e. the absorption edge of the spectrum shifts towards higher energies and the slope increases with rising sintering temperature $\left(600^{\circ} \mathrm{C}\right.$ to $\left.800^{\circ} \mathrm{C}\right)$. However, the spectrum shifts towards lower energies region above $800^{\circ} \mathrm{C}$ sintering temperature and the slope decreases.
\end{abstract}

\section{INTRODUCTION}

Cadmium sulfide (CdS) is a semiconductor used in microelectronic and optoelectronic applications. CdS has a wide bandgap (2.52eV at room temperature) and shows a direct transition which is characteristic of II -VI compound semiconductors. Reliable, nonintrusive characterization of CdS has recently become a major subject for investigation due to their applications in the solar cell and photocell technologies. Over the past few decades, a number of electrical and optical studies have been performed on CdS[1]. Although, several investigations of CdS single crystals have been carried out on the optical absorption, the optical absorption measurements on ceramic CdS have been a difficult problem.0ne of the applications of ceramic CdS is in solar cells[2,3] and it is useful to get information on optical absorption for device fabrication. In photothermal spectroscopy (PTS), one detects the signal directly proportional to the thermal energy induced by the absorbed photons. The PTS signal is less sensitive to light scattering effects than conventional spectroscopy. Thus it is useful tool to study the absorption spectra of ceramic CdS. Recently, heat production by nonradiative processes has been detected by 
several methods [4]. It is worthwhile to investigate the direct detection of the temperature changes resulting from nonradiative processes following light absorption. We present here the experimental results of the photon energy dependence of the direct detection of temperature changes following light absorption in ceramic CdS using a simple apparatus proposed by Brilmyer et a1. [4].

\section{EXPER I MENTAL}

Ceramic CdS plates were obtained by forming a high-purity CdS powder pressed at $3 \times 10^{3} \mathrm{~kg} / \mathrm{cm}^{2}$ and sintering over the temperature range from $600^{\circ} \mathrm{C}$ to $900^{\circ} \mathrm{C}$ in $N_{2}$ gas $(500 \mathrm{ml} / \mathrm{min}$.). The sintering period was varied from 0.5 hour to 3.0 hour in order to determine the best conditions. The thickness of the specimen was approximately $1 \mathrm{~mm}$. The cell for PTS measurements is described elsewhere[4-7]. For PTS measurements we employed a thermistor as a sensor for the temperature rise. The thermistor had a nominal resistance of $12 \mathrm{k} \Omega$ and a sensitivity of $480 \Omega / \mathrm{K}$ at $20^{\circ} \mathrm{C}$. In order to eliminate effects resulting from temperature changes of the surrounding air, a differential thermistor arrangement was used to compensate for changes in ambient temperature.PTS measurements were carried out over the range from $400 \mathrm{~nm}$ to $800 \mathrm{~nm}$ using a 500 W xenon arc lamp. At each wavelength, the light irradiated the PTS cell for 15 seconds. The PTS signal intensity was normalized to the incident light intensity measured by a Si photodiode.

\section{RESULTS AND DISCUSSION}

Fig. 1 shows the photon energy dependence of the PTS signal in ceramic CdS for different sintering periods at $710^{\circ} \mathrm{C}$. We find that the spectrum shifts towards the high energy region as the sintering period increases and it tends to saturate beyond 1.0 hour sintering. Hence, the sample of 1.0 hour sintering for each temperature was applied for the next PTS measurements. Fig.2 shows the photon energy dependence of PTS in ceramic CdS for

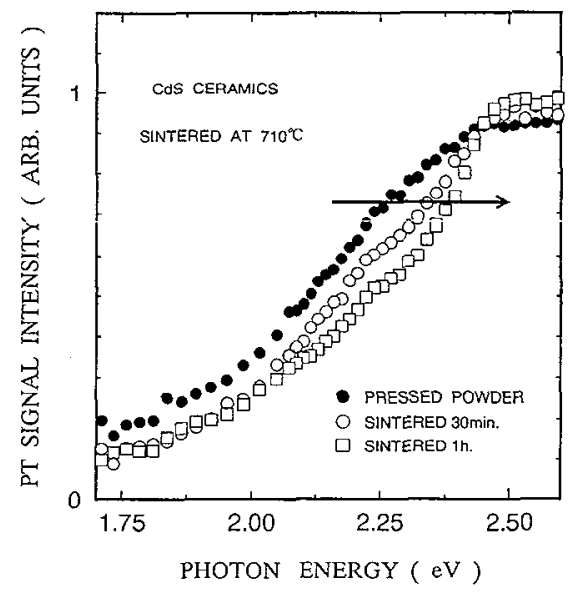

Fig. 1. Photon energy dependence of the PT signal intensity of ceramic CdS for different sintering times. 


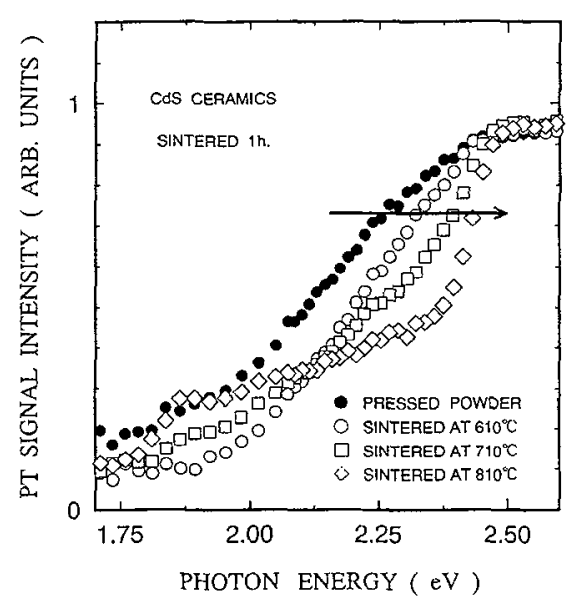

Fig.2. Photon energy dependence of the PT signal intensity of ceramic CdS for different sintering temperatures $\left(600^{\circ} \mathrm{C} \sim 800^{\circ} \mathrm{C}\right)$.

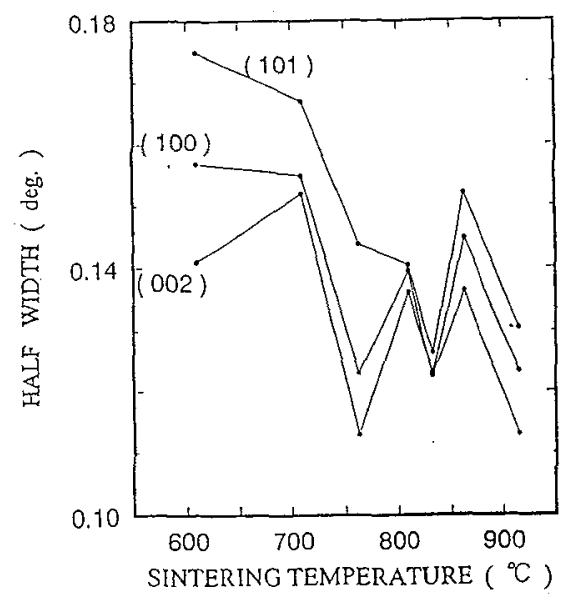

Fig. 4.Sintering temperature dependence of the half-widh of $X$ ray diffraction peaks for ceramic CdS.

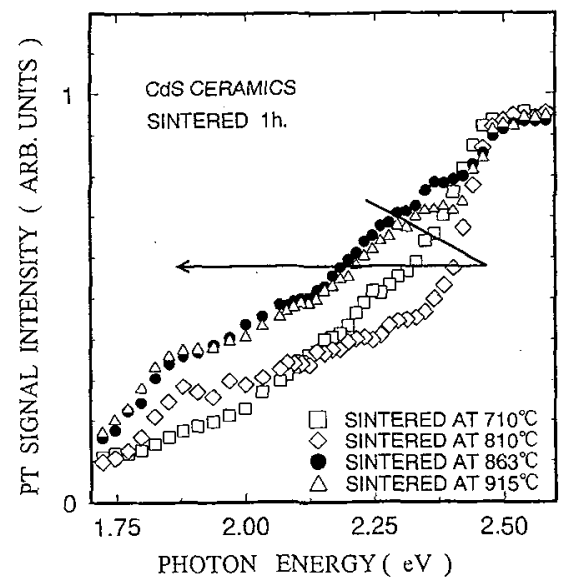

Fig. 3. Photon energy dependence of the PT signal intensity of ceramic CdS for different sintering temperatures $\left(700^{\circ} \mathrm{C} \sim 920^{\circ} \mathrm{C}\right)$.

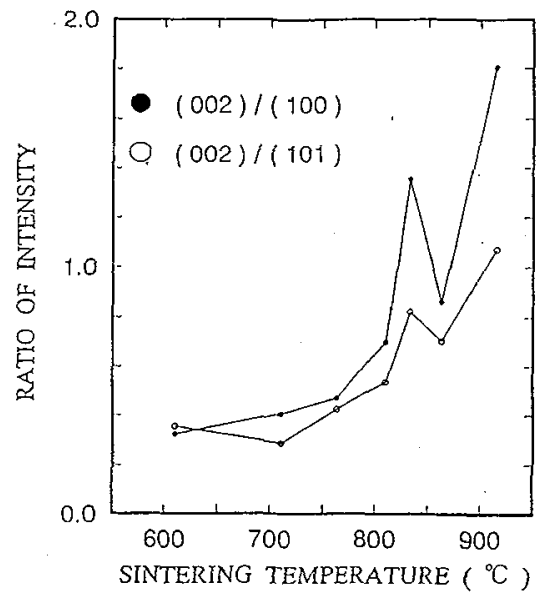

Fig.5. Sintering temperature dependence of the intensity ratio of X-ray diffraction peaks for ceramic CaS.

different sintering temperatures from $600^{\circ} \mathrm{C}$ to $810^{\circ} \mathrm{C}$. It is found that the spectrum shifts towards the high energy region and the slope of the absorption edge becomes steeper as the sintering temperature is in creased. Fig. 3 shows the photon energy dependence of PTS in ceramic CdS sintered at temperatures higher than $700^{\circ} \mathrm{C}$. In this temperature range 
the spectrum shifts towards 10 wer energies above $800^{\circ} \mathrm{C}$ sintering and the slope decreases for increasing temperature. The photon energy dependence of PTS in CdS single crystal has been measured and it shows steeper increasing than ceramic CdS at absorption edge. Figs. 4 and 5 show the sintering temperature dependence of the half-width and intensity ratio of $X$-ray diffraction peaks (100). (101) and (002)). It can be seen that halfwidth decreases for temperatures up to $750^{\circ} \mathrm{C}$ sintering temperature and remain constant above this value. Another trend is the orientation towards the (002) direction. The sintering temperature dependence of the average grain size measured by scanning electron microscopy (SEM) shows that it increases above $800^{\circ} \mathrm{C}$ sintering temperature. These results show the decreasing of structural randomess in ceramic CdS owing to the sintering process. The result of the PTS in Fig. 2 reflects the decreasing of structural randomess as the sintering temperature is increased. The sintering temperature dependence of the compositional raria, S/Cd, measured by electron probe micro analysis (EPMA) shows decreasing linearly at sintering temperature, indicating the formation of sulfur and cadmium vacancies. The result of the PTS in Fig. 3 might be related to the formation of defects during the sintering process. EPMA characterization shows that the shift of spectrum towards the lower energies above $800{ }^{\circ} \mathrm{C}$ sintering in Fig. 3 is related to the evaporation of CdS during the sintering processes which introduces the ionized donors (single and double) and deep levels (recombination center) [8]. At present, the experimental results cannot be adequately explained and clarification of the nature of the photothermal effect in ceramic CdS is left to future investigations. In the future, a study of relationships between formation of defects in sintering processes and photothermal spectra is needed to clarify the nature of nonradiative processes in ceramic CdS.

\section{REFERENCES}

[1] Mandelis A. and Siu E.K.M., Phys.Rev.B 34(1986)7209-7221.

[2] Nakayama N., Jpn. J.Appl.Phys.8(1969)450-462.

[3]Banerjee S. and Saha H., J.Phys.D:App1.Phys.16(1983)185-195.

[4] Brilmyer G.H., Fujishima A. Santhanam K.S.V. and Bard A.J., Anal.Chem. $49(1977) 2057-2062$.

[5]Fujishima A., Masuda H. and Honda K. Ana1. Chem.52(1980)682-685.

[6]Brilmyer G.H. and Bard A.J., Anal. Chem.52(1980)685-691.

[7] Fujishima A., Maeda Y. and Honda K.,Bul1 Chem.Soc.Jpn.53(1980)2735-2741.

[8] Siu E.K.M. and Mandelis A., Phys. Rev. B 34(1986)7222-7233. 